$\underline{\text { Avicenna Journal of Nursing and Midwifery Care - ISSN 2676-5748 }}$

\title{
The Relationship Between Emotional Intelligence and Job Stress and Occupational Exhaustion among Nurses of Health Care Centers in University Medical Sciences of Hamadan in 2014
}

\section{Nastaran Soltan Abadi ${ }^{*}$, Ali Beikmoradi ${ }^{2}$}

1. MSc, Department of Nursing, School of Nursing and Midwifery, Hamadan University of Medical Sciences, Hamadan, Iran

2. Professor, Department of Nursing, School of Nursing and Midwifery, Hamadan University of Medical Sciences, Hamadan, Iran

\begin{tabular}{|c|c|}
\hline Article Info & ABSTRACT \\
\hline $\begin{array}{l}\text { Received: } 2019 / 05 / 11 \\
\text { Accepted: } 2020 / 04 / 10 \\
\text { Published Online: } 2020 / 08 / 22\end{array}$ & $\begin{array}{l}\text { Introduction: Using emotional intelligence, nurses will be more adaptable to } \\
\text { their environment and job stress and will have less burnout in the workplace. The } \\
\text { aim of this study was to investigate the relationship between emotional intelligence } \\
\text { and job stress and occupational burnout among nurses in intensive care units. }\end{array}$ \\
\hline dol $10.30699 / a j n m c .28 .3 .181$ & $\begin{array}{l}\text { Methods: A descriptive cross-sectional correlation study with random stratified } \\
\text { sampling method, } 205 \text { nurses of intensive care units in the educational and health } \\
\text { centers (Beheshti, Ekbatan, Behesht, Farshchian and Fatemiyeh) in Hamedan city in } \\
2014 \text { were conducted. Data was collected by questionnaire of Emotional } \\
\text { Intelligence-Load, Philip L. Rice's Job Stress, and Meslach's Burnout Questionnaire. }\end{array}$ \\
\hline $\begin{array}{l}\text { Use your device to scan } \\
\text { and read the article online }\end{array}$ & $\begin{array}{l}\text { Results: Special care nurses had a mean score of moderate emotional intelligence } \\
(233.13 \pm 12.71) \text { and the mean of occupational stress score }(169.30 \pm 14.16) \text { and the } \\
\text { mean score of burnout components were emotional exhaustion }(29.96 \pm 13.77) \text { and } \\
\text { personality deprivation }(11.55 \pm 8.87) \text { and personal capability }(35.78 \pm 11.85) \text {. } \\
\text { Emotional intelligence with job stress }(P=0.01, \mathrm{r}=-0.28) \text { also, the burnout } \\
\text { components of emotional exhaustion }(P=0.01, \mathrm{r}=-0.44), \text { personality } \\
\text { depersonalization }(P=0.01, \mathrm{r}=-0.37) \text { and personal adequacy }(P=0.01, \mathrm{r}=-0.37) \text { had a } \\
\text { reverse and significant relationship. }\end{array}$ \\
\hline 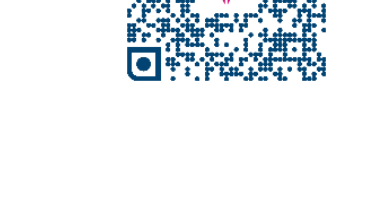 & $\begin{array}{l}\text { Conclusion: Job stress can lead to physical or psychological harm and in the long } \\
\text { run lead to negative outcomes in the performance of nurses and hospitals; in the long } \\
\text { run, this leads to burnout in nurses and reduced ability to care for patients. Actions such } \\
\text { as paying attention to the concept of emotional intelligence and promoting it in the } \\
\text { nursing profession can be considered in preventing such problems. }\end{array}$ \\
\hline
\end{tabular}

Keywords: Emotional Intelligence, Job Stress, Burnout

\footnotetext{
Corresponding Information: $\quad$ Nastaran Soltan Abadi, MSc, Department of Nursing, School of Nursing and Midwifery, Hamadan University of Medical Sciences, Hamadan, Iran.

Email: nastaransoltanabadi95@gmail.com

Copyright (C) 2020, This is an original open-access article distributed under the terms of the Creative Commons Attribution-noncommercial 4.0 International License which permits copy and redistribution of the material just in noncommercial usages with proper citation.
}

\section{How to Cite This Article:}

Soltan Abad N, Beikmoradi A. The Relationship Between Emotional Intelligence and Job Stress and Occupational Exhaustion among Nurses of Health Care Centers in University Medical Sciences of Hamadan in 2014. Avicenna J Nurs Midwifery care. 2020; 28 (3) : 


\section{بررسى رابطهُ هوش هيجانى با تنش شغلى و فرسودَى شغلى :برستاران بخشهاى مراقبت ويزه مراكز

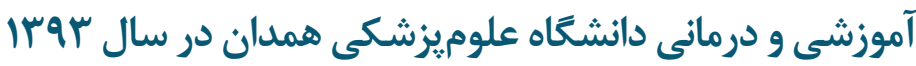 \\ نسترن سلطان آبادى '*، على بيكمرادى}

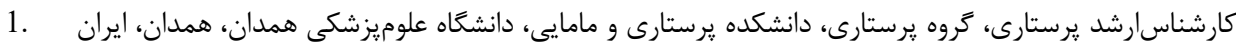

2. استاد، گروه يرستارى، دانشكده يُرستارى و مامايى، دانشخاه علوميزشكى همدان، همدان، ايران

\begin{tabular}{|c|c|}
\hline جكيده & اطلاعات مقاله \\
\hline 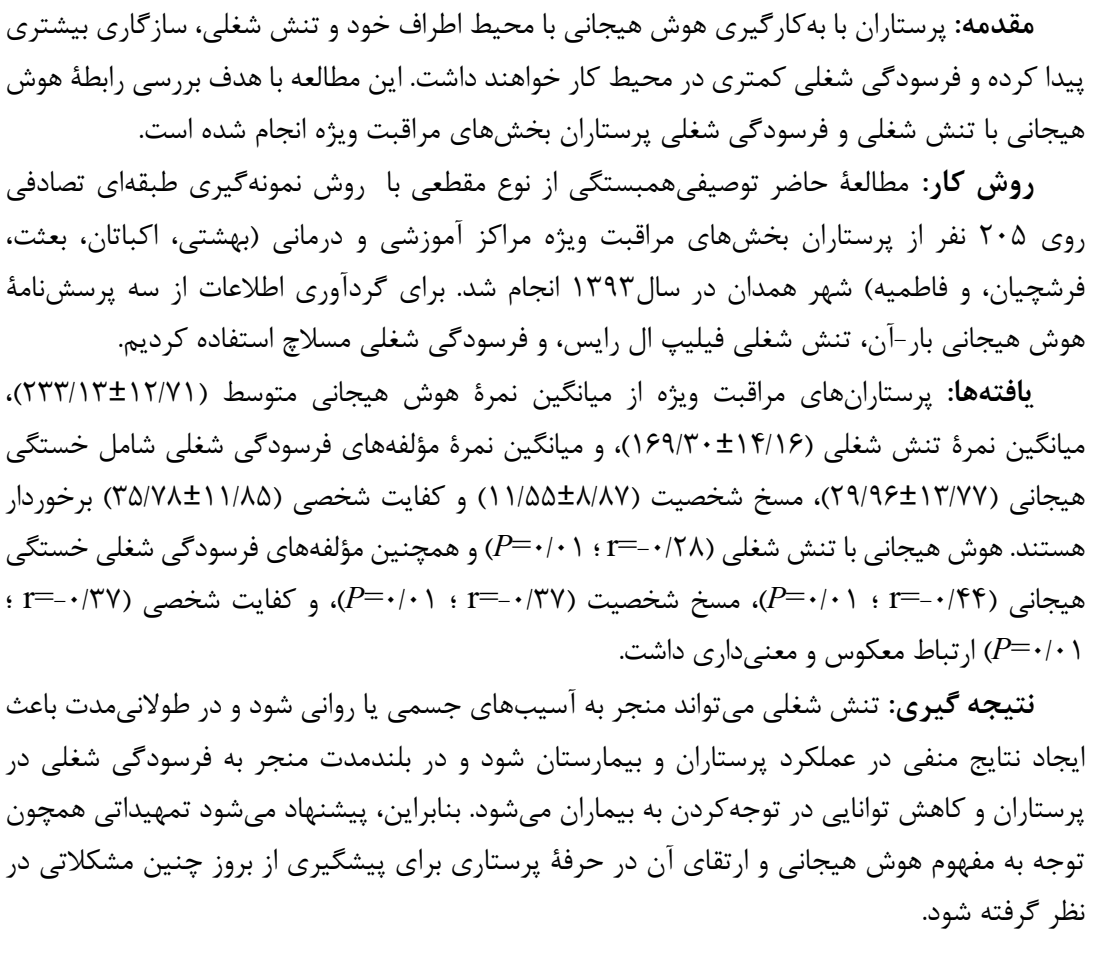 & 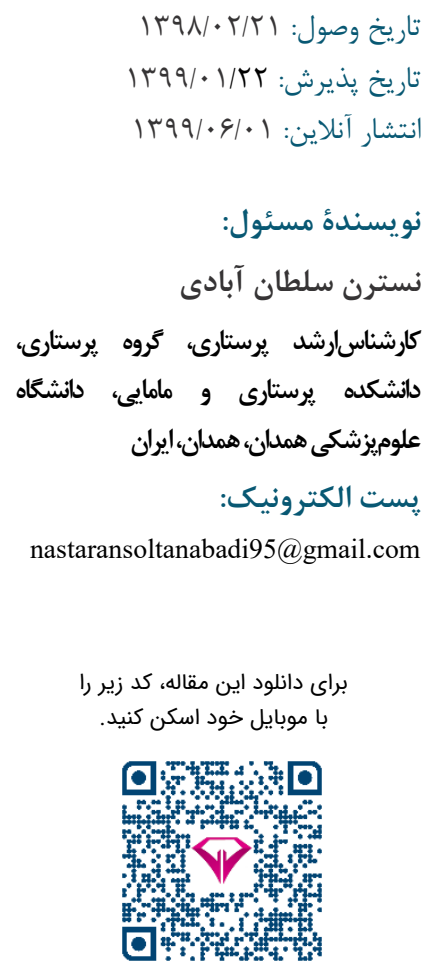 \\
\hline كليدوازهها: هوش هيجانى، تنش شغلى، فرسودىى شغلى & \\
\hline
\end{tabular}

امراض روحى، جسمى و رفتارى در سازمانها تلقى مى گردد

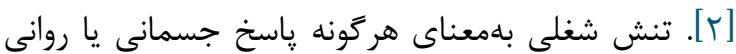

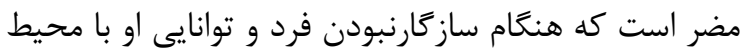

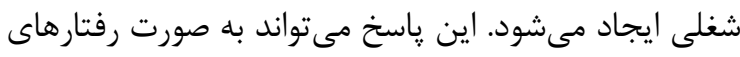

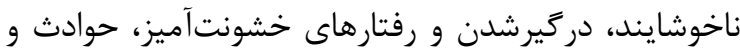
مصدوميتهاى كار يا بيمارىهاى جسمانى مختلف بروز كند

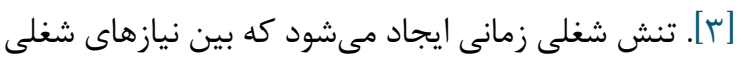
و قابليتها و خواستههاى فرد هماهنگى نباشد [ب].
ازجمله محركهاى محيطى فشارزاى مهمى كه مى تواند سبب فشار روانى مزمن شود، نوع شغلى است كه شخص به محسيه

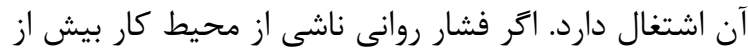
حد شود، مىتواند سبب عوارض جسمى و روانى براى فرد فرد شود، سلامت وى را به مخاطره اندازد، اهداف سازمانى را تهديد كند و به كاهش كيفيت عملكرد فرد منجر شود. افراد شاغلى كه در محيط كار خود بلنوعى در گير اين نوع فشارها هستند، اغلب به تنش و فرسودگى شغلى مبتلا مى شوند [1]. تنش شغلى بلهعنوان مهمرترين عامل بهوجودآورنده 
شغلى تنها نتيجة استرس نيست، بلكه هوش هيجانى نيز سهم

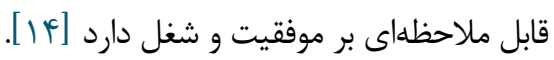

هوش هيجانى، نوعى بردازش اطلاعات عاطفى است كه

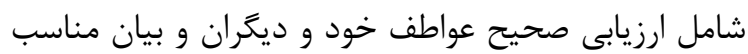

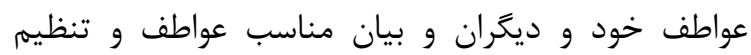

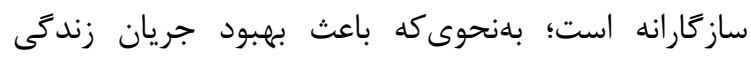

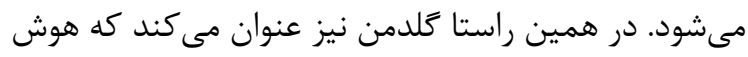
هيجانى قادر است در محيطهاى كارى، روابط عاطفى

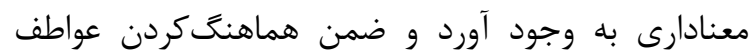
كاركنان در محيطهاى كارى، زمينهٔ تبادل احساسات مثبت

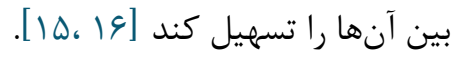
Benson

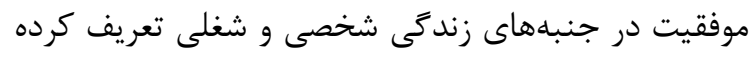

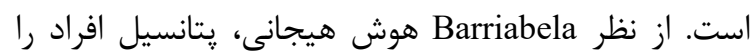
براى سازكارى بهتر و تجربه تنش كمتر و حفظ سلامتى

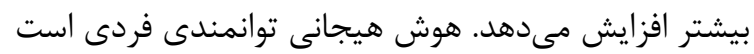

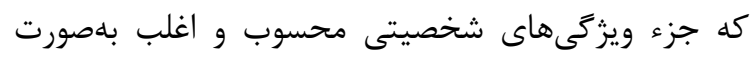
خود كزارشى اندازهيرى مىشود. اين توانمندى در ساز كارى، موفقيت، رشد هوشى، مديريت خود فرد و احساسات ديكران

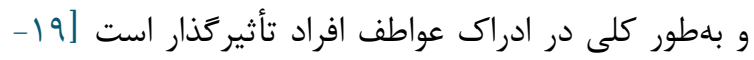

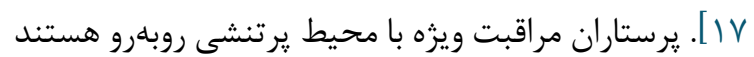
و تنش شغلى زيادى را بهطور روزمره تجربه مى كنند.

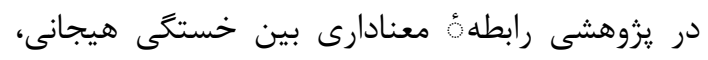

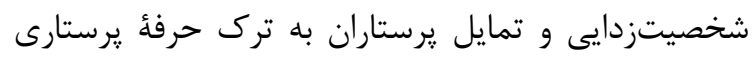

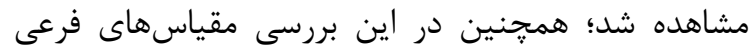

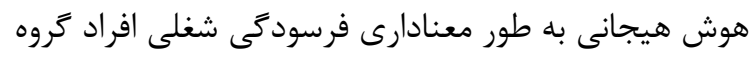

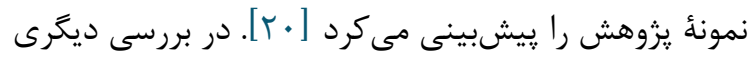
مشخص شد هوش هيجانى نقش مهمى در شكل كيرى روابط

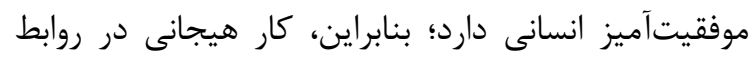

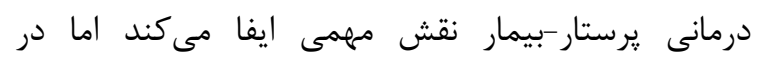

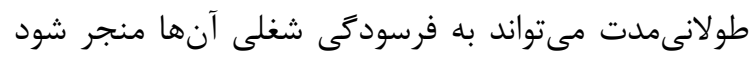

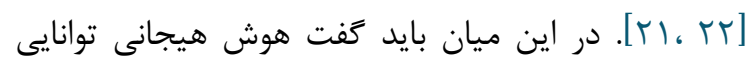

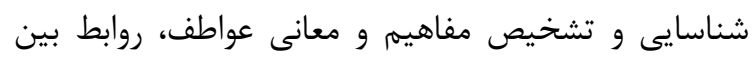

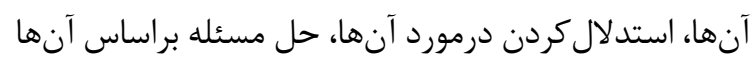

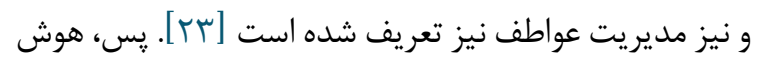

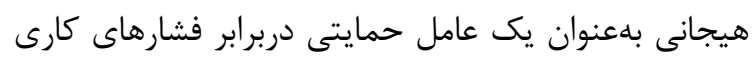

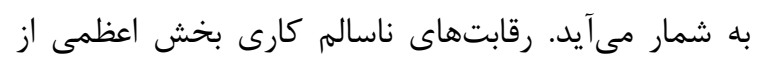

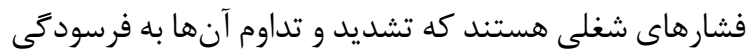

منظور از تنش شغلى فرد سه نوع تنش موجود در

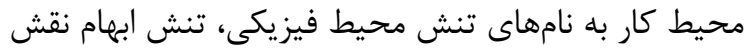

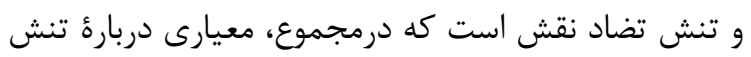

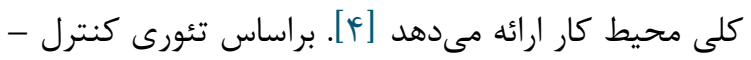
تقاضا تنش شغلى زمانى رخ مىدهد كه ميزان تقاضاهاى روانى كار زياد و كنترل روى كار يا تصميم كيرى كم باشد نداند

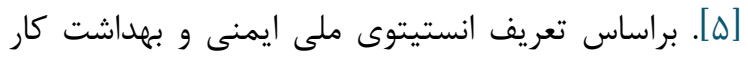
تنش شغلى عبارت است از هر كونه واكنش غير مفيد روانى

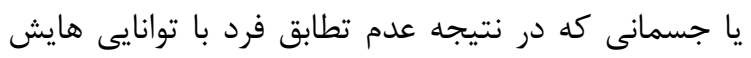
حاصل مىشود كه مىتواند سبب بروز رفتارهاى يرخاشكر انهانه،

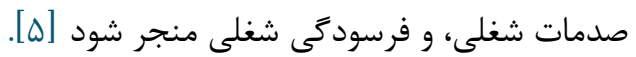

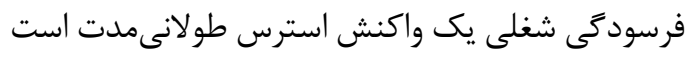

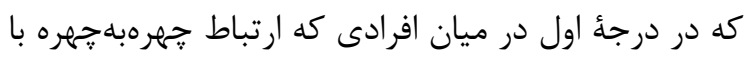

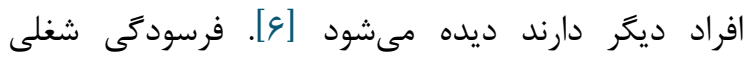
سندرمى مشتمل بر خستخى هيجانى، مسخ شخصيت و

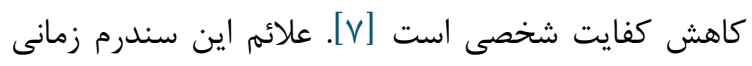
آشكار مىشود كه توانايى هاى فرد براى تقاضاهاى محيط كار كافى نباشد. خستكى هيجانى (خستكى مزمن، اختلالات

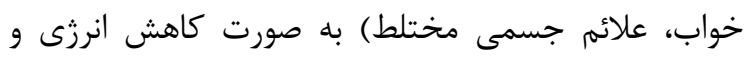

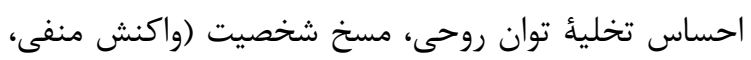

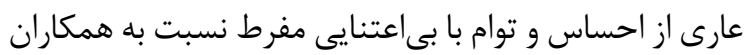

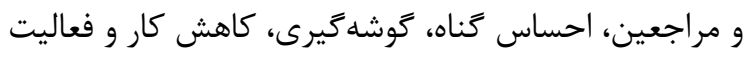

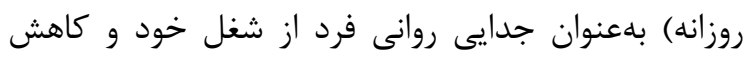
احساس كفايت شخصى (كاهش احساس شايستكى و و رونى

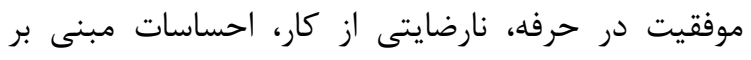

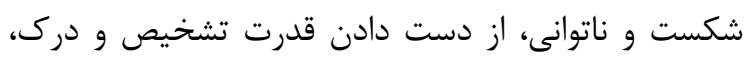

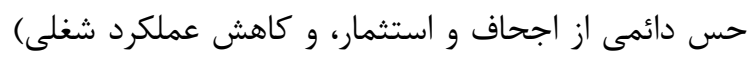

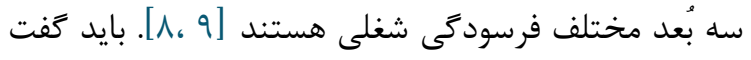

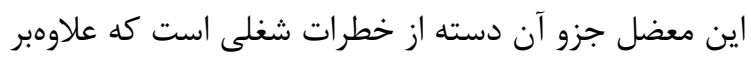

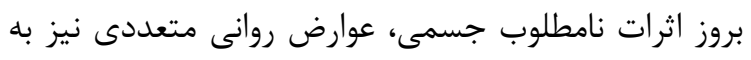

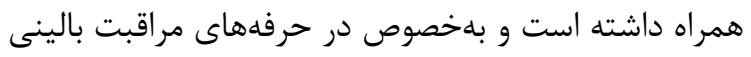

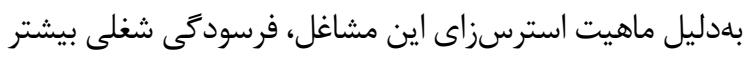

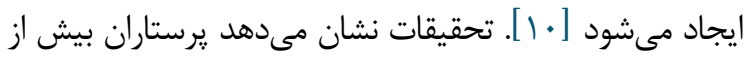

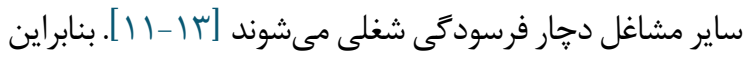

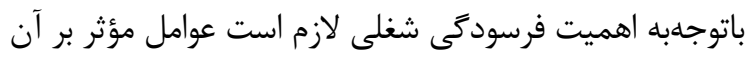

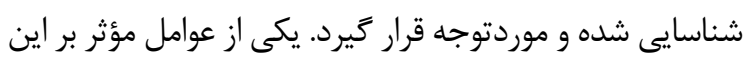

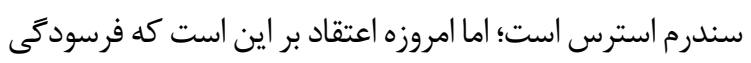


مقياس ينجدرجهاى ليكرت نمرهكذارى از ه تا يك (كاملاً

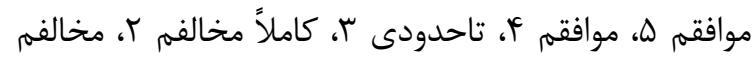

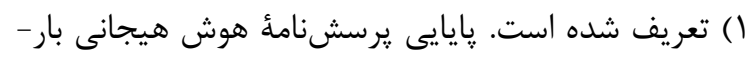

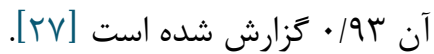

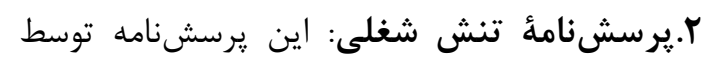

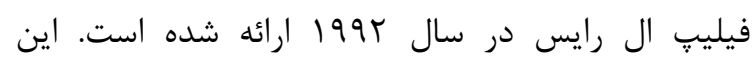

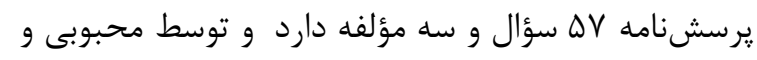

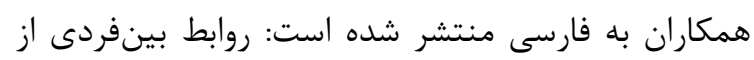

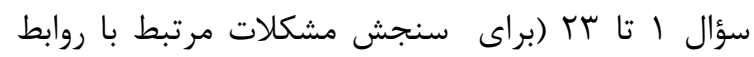

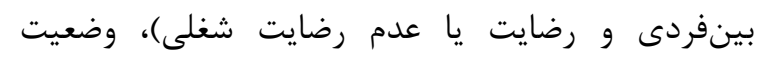

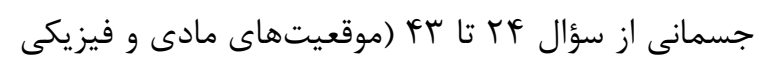

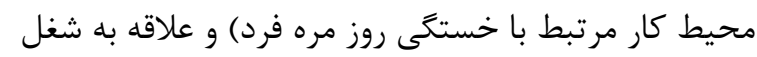

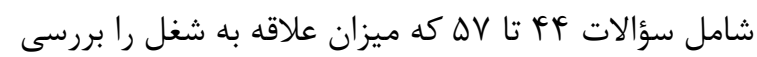

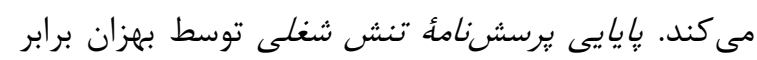

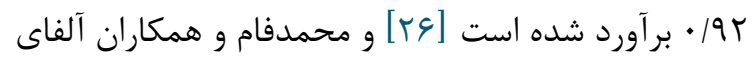

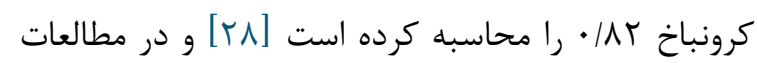

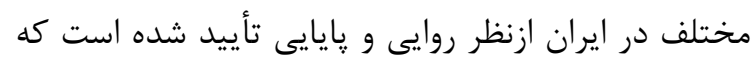

به بيوست است.

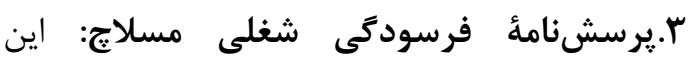

يرسشنامه توسط مسلاج و همكاران در سال (999)

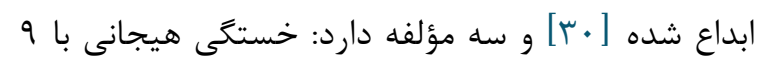

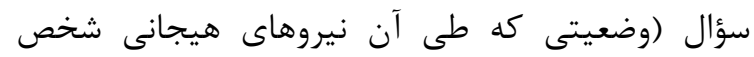

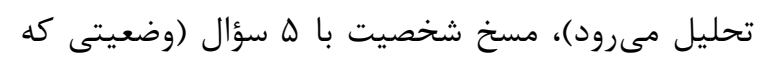

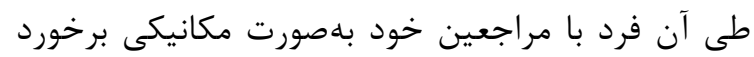

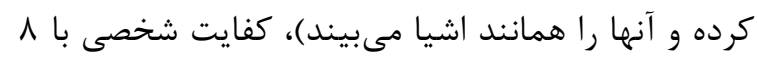

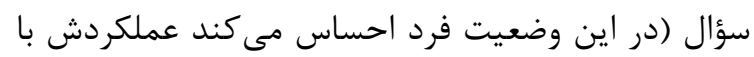

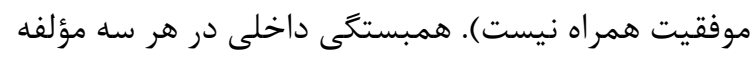

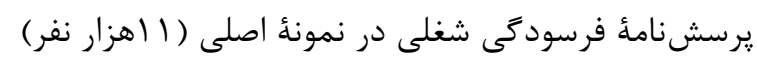

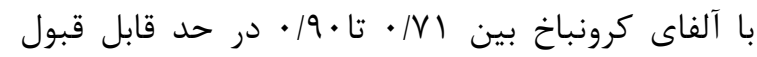

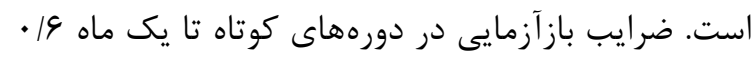

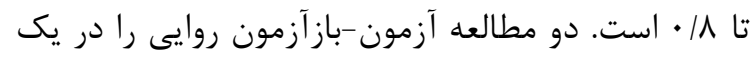

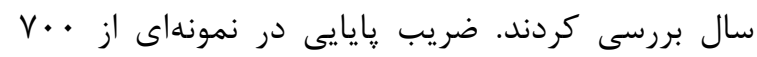

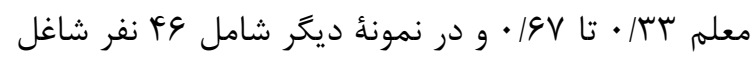

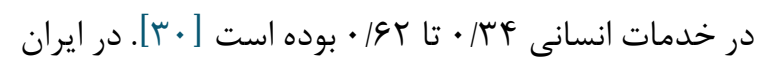
نيز اعتبار و روايى اين ابزار بررسى شده است. Momeni

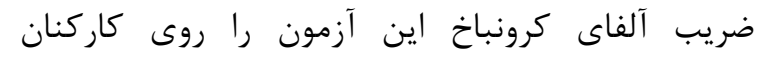

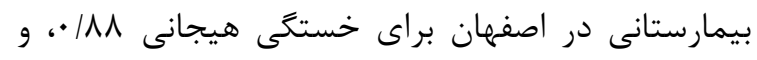

شغلى منجر مىشود. بنابراين، هوش هيجانى با مديريت

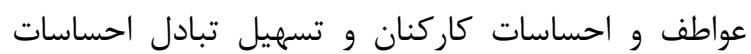

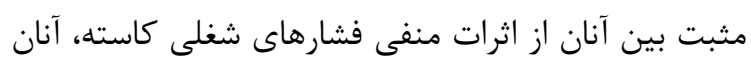

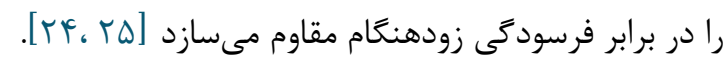

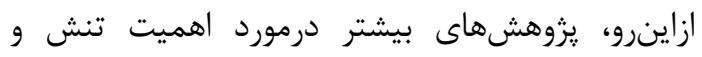

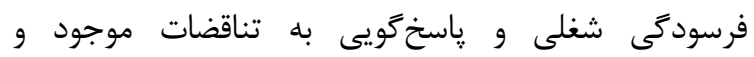

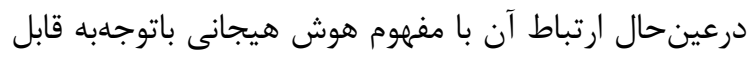

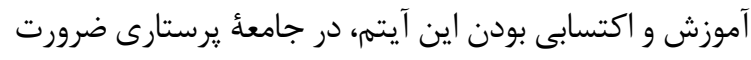

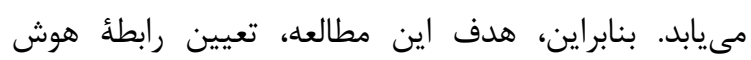

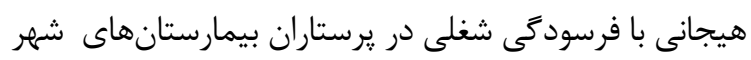

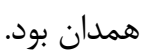

\section{روش بررسى}

اين يزوهش از نوع يزوهش هاى توصيفى همبستخى بود.

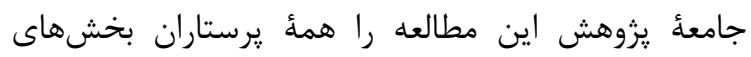

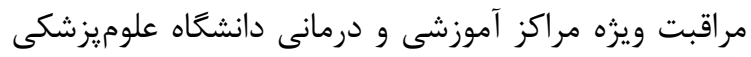
همدان (شهيد بهشتى، اكباتان، بعثت، فرشجيان، و وراطميه) تشكيل داده است. در اين مطالعه با فرض كمترين ضريب همبستكى بين

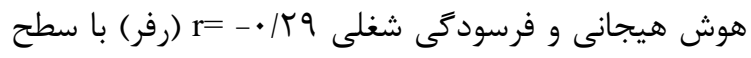

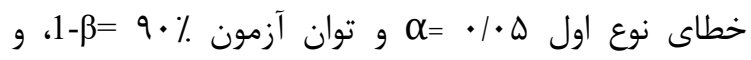

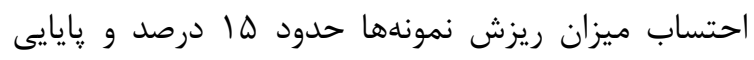

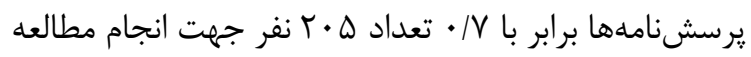

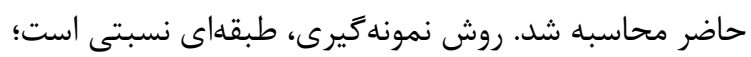

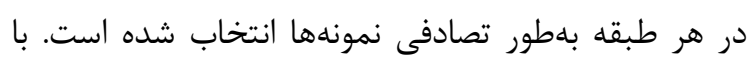

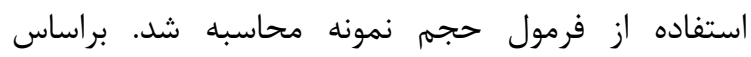

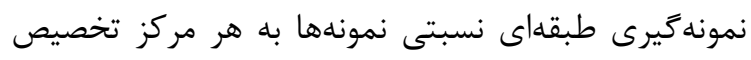

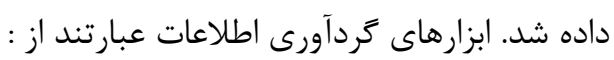

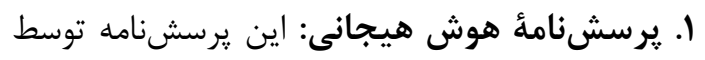

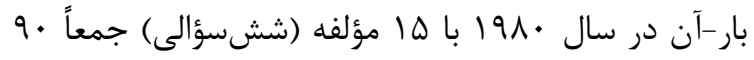

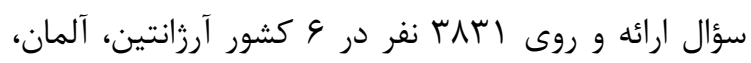

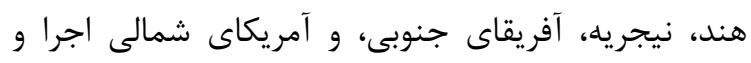

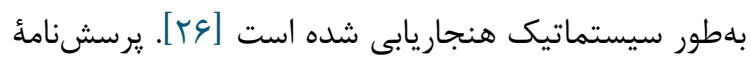

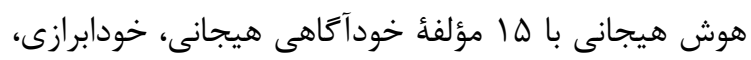

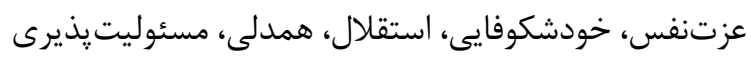

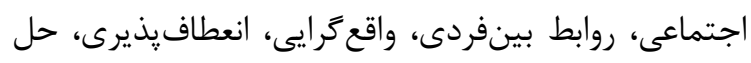

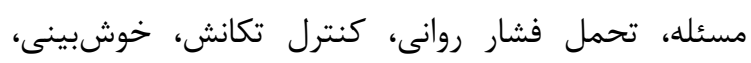

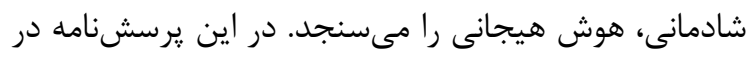


جدول r نشانكر آن است كه بيشترين (V/ • د درصد) يرستاران

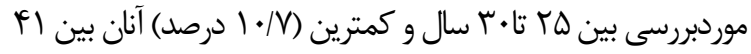

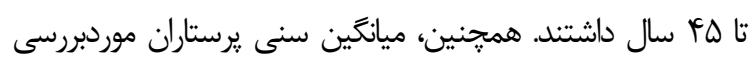

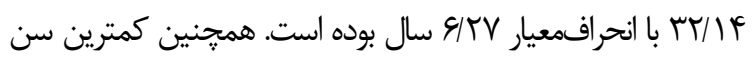

$$
\text { يرستاران موردبررسى ها و بيشترين هأl سال بوده است. }
$$

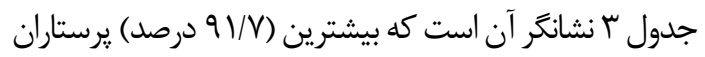

$$
\text { موردبررسى كارشناس و بقيه آنان كارشناس ارشد بودهاند. }
$$

براى كفايت شخصيت V9/ • و براى كل آزمون r/|• به

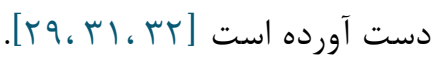

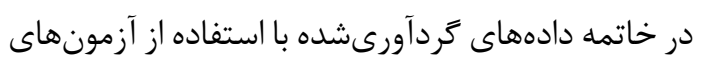

ضريب همبستخى پيرسون و رگرسيون جند خانه با نرمافزار (SPSS Inc., Chicago, Ill., USA) SPSS

\section{بافته ها}

$$
\begin{aligned}
& \text { جدول ا نشانكر آن است كه بيشترين ( VY/1 درصد) برستارانٍ }
\end{aligned}
$$

\begin{tabular}{|c|c|c|}
\hline درصد & تعداد & جنس \\
\hline$r \Delta / q$ & $\Delta r$ & مرد \\
\hline$V \Psi / l$ & IDT & زن \\
\hline $1 \cdots$ & $r \cdot \Delta$ & جمع \\
\hline
\end{tabular}

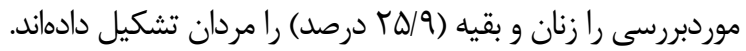

جدول ا. توزيع فراوانى يرستاران بخشهاى مراقبت ويزه براساس جنس

\begin{tabular}{|c|c|c|}
\hline درصد & تعداد & سن (سال) \\
\hline$\Delta \cdot / V$ & $1 \cdot f$ & $r \cdot-r \Delta$ \\
\hline$r r / q$ & $4 q$ & $r \Delta-r \mid$ \\
\hline $\mid f / 9$ & $r$. & $\boldsymbol{q} \cdot-r_{\boldsymbol{q}}$ \\
\hline $1 \cdot / V$ & Tr & 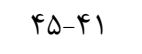 \\
\hline $1 \cdots$ & $r \cdot \Delta$ & جمع \\
\hline
\end{tabular}

جدول r. توزيع فراوانى برستاران بخشهاى مراقبت ويزه براساس سن

\begin{tabular}{|c|c|c|}
\hline درصد & تعداد & ميزان تحصيلات \\
\hline $91 / V$ & $1 M \Lambda$ & كارشناسى \\
\hline$\Lambda / r$ & IV & كارشناسى ارشد \\
\hline $1 \cdots$ & $r \cdot \Delta$ & جمع \\
\hline
\end{tabular}

جدول r. توزيع فراوانى يرستاران بخشهاى مراقبت ويثه براساس ميزان تحصيلات

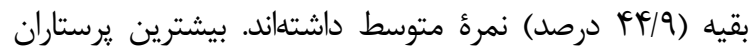

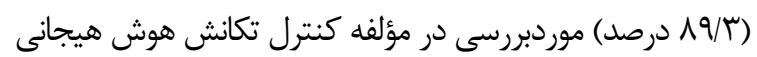

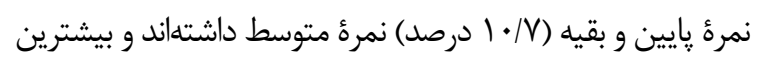

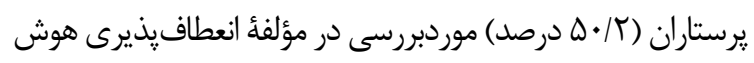

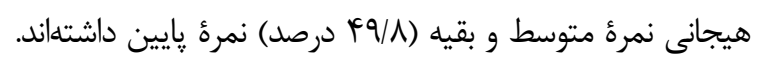

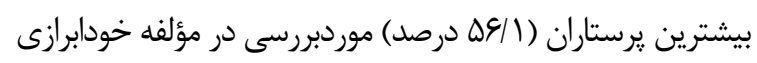

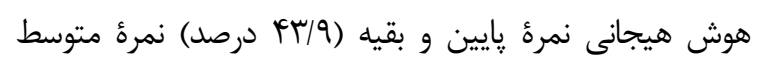
داشتهاند.
جدول \& نشانكر آن است كه بيشترين (FNH درصد) يرستاران موردبررسى مجرد وكمترين (\$א/ه درصد) آنان مطلقه بودند.

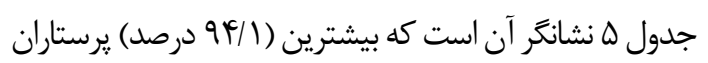
موردبررسى نمرة كل هوش هيجانى متوسط ويايينى، كمترين

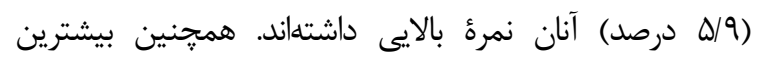
يرستاران (V9 درصد) موردبررسى در مؤلفه ميزان استقلال هوش دمان

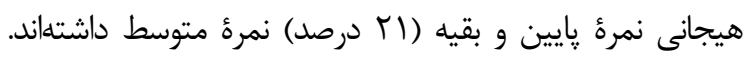

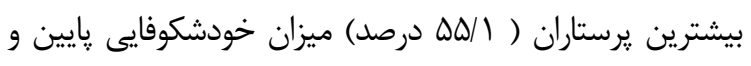

\section{جدول f. توزيع فراوانى يرستاران بخشهاى مراقبت ويثه براساس وضعيت تاهل}

\section{درصد}

\section{وضعيت ناهل}




\begin{tabular}{|c|c|c|c|c|c|c|c|c|}
\hline & & \multicolumn{2}{|c|}{$9 \Delta$} & \multicolumn{5}{|c|}{ متاهل } \\
\hline & & \multicolumn{2}{|c|}{99} & \multicolumn{5}{|c|}{ مجرد } \\
\hline & & \multicolumn{2}{|c|}{11} & \multicolumn{5}{|c|}{ مطلقه } \\
\hline & & \multicolumn{2}{|c|}{$r \cdot \Delta$} & \multicolumn{5}{|c|}{ جمع } \\
\hline \multicolumn{9}{|c|}{ جدول ه. توزيع فراوانى يرستاران بخش هاى مراقبت ويزه براساس نمرهٔ هوش هيجانى و مؤلفههاى آن } \\
\hline \multirow{2}{*}{ 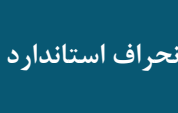 } & \multirow{2}{*}{ ميانكين } & \multicolumn{2}{|c|}{ 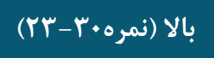 } & \multicolumn{2}{|c|}{ 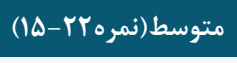 } & \multicolumn{2}{|c|}{ 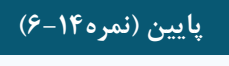 } & \multirow{2}{*}{ متغير } \\
\hline & & درصد & فراوانى & درصد & فراوانى & درصد & فراوانى & \\
\hline$T / T \Lambda$ & $1 \% / 9 \Lambda$ & $\Delta / 9$ & IT & $\Delta \Lambda$ & 119 & $r \varphi / 1$ & VF & حل مسئله \\
\hline$r / D \mid$ & $1 V / r q$ & $\cdot$ & $\cdot$ & $9 N / r$ & If. & rI/V & $9 D$ & خوشبختى \\
\hline$r / 1 \Lambda$ & $\mid \Delta / \cdot \Delta$ & · & · & TI & pr & V9 & 194 & استقلال \\
\hline $1 / 9 \Delta$ & $\mid r / F \Lambda$ & $\cdot$ & · & 09 & $|r|$ & (I) & $\Lambda f$ & تحمل فشار روانى \\
\hline$r / r)$ & $|f / r|$ & $\cdot$ & · & $f F / q$ & 94 & $\Delta \Delta / 1$ & $11 \pi$ & خودشكوفايى \\
\hline$r / \cdot \Delta$ & $1 r / 9 \Delta$ & $\cdot$ & · & $V I / T$ & If4 & TN/A & $\Delta 9$ & خودآكاهى هيجانى \\
\hline$T / T G$ & $10 / r q$ & $\cdot$ & · & YI & pr & V9 & IST & واقع كرايى \\
\hline $1 / 91$ & $\mid Y / F F$ & $T F / F$ & $\Delta \cdot$ & $V I / T$ & If4 & $f / f$ & 9 & 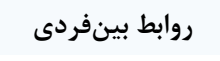 \\
\hline$\Psi / \cdot V$ & $19 / \pi \Delta$ & $11 / \mathrm{V}$ & TF & $\Lambda r / 9$ & IV. & $\Delta / \mathcal{F}$ & 11 & 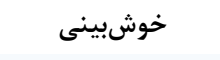 \\
\hline$T / V T$ & $\mid N / 1$. & $|V /|$ & ra & $\Lambda \cdot 10$ & 190 & $r / \mathcal{F}$ & $\Delta$ & عزتنفس \\
\hline$r / 9 T$ & $1 N / V \Delta$ & · & · & $1 \cdot / V$ & Tr & 19/r & INr & كنترل تكانش \\
\hline$r / T \Lambda$ & $1 \cdot 19$. & $\cdot$ & . & $\Delta \cdot / r$ & $1 \cdot r$ & $r q / \Lambda$ & $1 \cdot r$ & انعطاف يذيرى \\
\hline$r / 9 T$ & $|F| \cdot V$ & $14 / 9$ & $r$. & $\Lambda T / F$ & 199 & $r / 9$ & 9 & 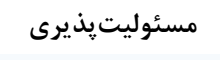 \\
\hline T/AT & $1 N / V$. & 11 & rv & $v \wedge$ & 19. & $r / 9$ & $\wedge$ & همدلى \\
\hline$r / 99$ & $1 N / 94$ & $\cdot$ & $\cdot$ & $p r / q$ & 9. & $\Delta S / 1$ & 110 & خودابزارى \\
\hline$|Y / V|$ & זואזr & $f / f$ & 9 & $\Lambda \varepsilon / \Lambda$ & $I V A$ & $\Lambda / \Lambda$ & 11 & هوش هيجانى \\
\hline
\end{tabular}

بالايى داشتهاند. بيشترين (T//T درصد) يرستاران موردبررسى نمرة تنش شغلى رادر مؤلفه علاقه به شغل متوسط و كمترين (NA درصد)

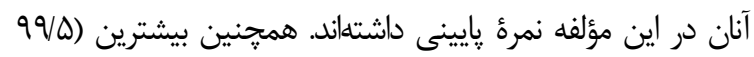

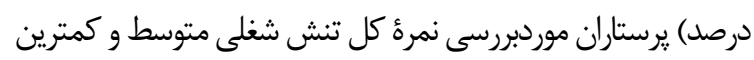
(ه درصد) آنان تنش شغلى پإيينى داشتهاند.
جدول 9 نشانكر آن است كه بيشترين (9V/9 درصد) يرستاران موردبررسى نمره تنش شغلى را در مؤلفهُ روابط بينفردى متوسط و

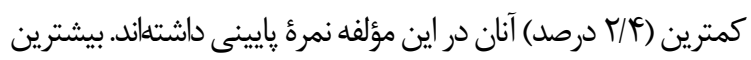

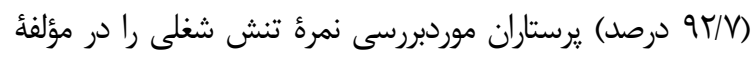
وضعيت جسمانى متوسط و كمترين (r درصد) آنان در اين مؤلفه نمره

جدول و. توزيع فراوانى ثرستاران بخشهاى مراقبت ويثه براساس نمرهُ تنش شغلى و مؤلفههاى آن

\begin{tabular}{|c|c|c|c|c|c|c|c|c|}
\hline \multirow{2}{*}{ انحرافمعيار } & \multirow{2}{*}{ ميانتين } & \multicolumn{2}{|c|}{ بالا } & \multicolumn{2}{|c|}{ متوسط } & \multicolumn{2}{|c|}{ يايين } & \multirow{2}{*}{ تنش شغلى و مؤلفههاى آن } \\
\hline & & درصد & تعداد & درصد & تعداد & درصد & تعداد & \\
\hline$\Delta / \wedge \Lambda$ & $9 \Delta / q^{\prime}$ & - & - & $9 \vee / 9$ & $r \cdot \cdot$ & $r / \mathcal{A}$ & $\Delta$ & روابط بينفردى \\
\hline $9 / 19$ & $9 V / T \Lambda$ & $r$ & r & $9 T / V$ & 19. & $\Delta / \uparrow^{\epsilon}$ & 11 & وضعيت جسمانى \\
\hline r & $r V / q 1$ & - & • & $91 / \pi$ & IAV & $\Lambda / \Lambda$ & 11 & علاقه به شغل \\
\hline $1 f / 19$ & $199 / \mu$. & . & - & $99 / \Delta$ & $r \cdot r$ & $\cdot 10$ & 1 & نمرهُ كل تنش شغلى \\
\hline
\end{tabular}

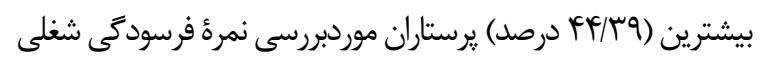

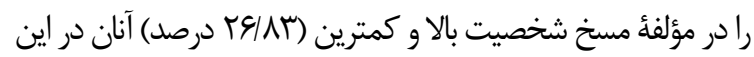

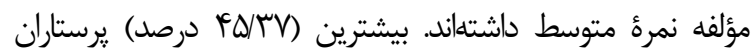

جدول V نشانكر آن است كه بيشترين (Y · P درصد) يرستاران

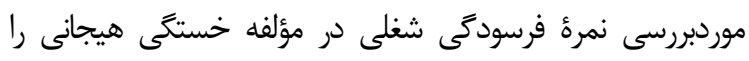
متوسط و كمترين آنان (צس/W دمرصد) در اين مؤلفه نمرة بالا داشتهاند. 
درصد) و مسخ شخصيت بالا (F/ F/F درصد) و ميزان نمرة بـ كفايتى

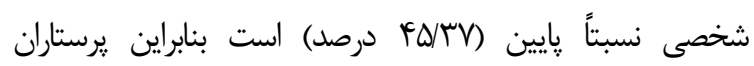
موردبررسى دجار فرسودگى شغلى ازنظر شدت هستند.
موردبررسى نمرؤ فرسودىى شغلى را در مؤلفه بى كفايتى شخصى بالا

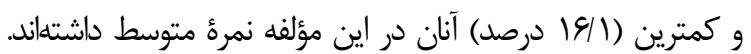

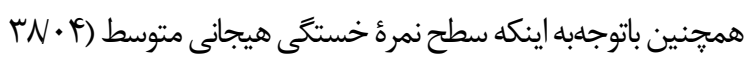

جدول V. توزيع فراوانى يرستاران بخشهاى مراقبت ويزه در مؤلفههاى فرسودىى شغلى براساس ميزان شدت

\begin{tabular}{|c|c|c|c|c|c|c|c|c|}
\hline \multirow{2}{*}{ انحراف استاندارد } & \multirow{2}{*}{ ميانگين } & \multicolumn{2}{|c|}{ بالا } & \multicolumn{2}{|c|}{ متوسط } & \multicolumn{2}{|c|}{ يايين } & \multirow{2}{*}{ مؤلفههاى فرسودَى شغلى (شدت) } \\
\hline & & درصد & تعداد & درصد & تعداد & درصد & تعداد & \\
\hline$I T / V V$ & rq/9६ & $r \Delta / T_{C}$ & $\Delta T$ & $r N / \cdot r$ & $\vee \wedge$ & re/Dq & $V \Delta$ & خستتى هيجانى \\
\hline N/AV & $11 / \Delta \Delta$ & $F F / r q$ & 91 & T\&/AT & $\Delta \Delta$ & TN/VA & $\Delta 9$ & مسخ شخصيت \\
\hline $11 / \wedge \Delta$ & $r \Delta / v \wedge$ & $F \Delta / T V$ & $9 \pi$ & $19 / 1$ & 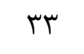 & TN/QT & vq & بى كفايتى شخصى \\
\hline
\end{tabular}

نمرئ هوش هيجانى كلى و برخى از مؤلفهاى هوش هيجانى

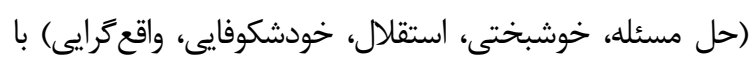

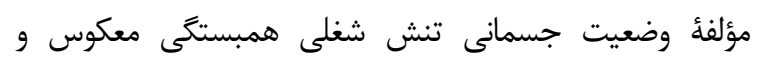

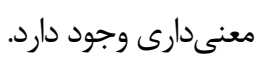

نمرئ هوش هيجانى كلى و برخى از مؤلفههاى هوش هيجانى دارد

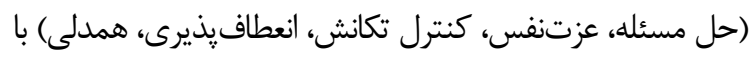

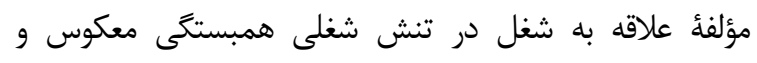

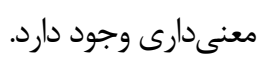

جدول 1 نشانكر آن است كه بين هوش هيجانى كلى و تنش شغلى كلى همبستخى معكوس و معنى دارى وجود دارد. همجنين إنين

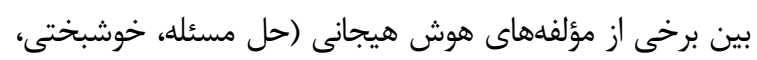

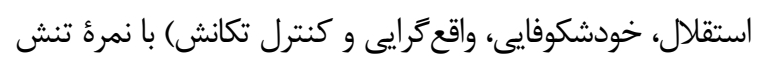
شغلى كلى همبستگى معكوس و معنى دارى وجود دارد.

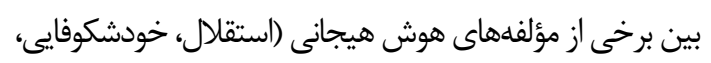

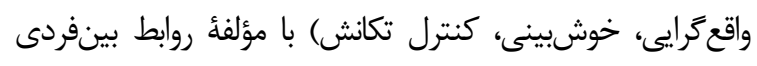
تنش شغلى همبستخى معكوس و معنى دارى وجود دارد.

\begin{tabular}{|c|c|c|c|c|}
\hline علاقه به شغل & وضعيت جسمانى & روابط بينفردى & تنش شغلى & \\
\hline$-\cdot / T V^{* * *}$ & $-\cdot / Y Y^{* * a}$ & .1 .9 & $-\cdot / \Gamma \Lambda^{* * * *}$ & هوش هيجانى \\
\hline$-\cdot|r|^{* * *}$ & $-\cdot / 1 f^{*}$ & .1 .9 & $-\cdot / r \cdot \%$ & حل مسئله \\
\hline .1 .99 & $-\cdot / r \Delta^{* * *}$ & $-.1 \cdot 4$ & $-\cdot / 19^{*}$ & خوشبختى \\
\hline.$- / . r t r$ & $-\cdot / \Gamma \Delta^{* m}$ & $-\cdot / 1 Q^{*}$ & $-\cdot / Y Y^{* * a s}$ & استقلال \\
\hline$-\cdot 11$ &.$- / \cdot \Delta$ & -.1 .9 & -.1 .9 & تحمل فشار روانى \\
\hline-.1 .4 & $-\cdot / 1 \Lambda^{* * *}$ & $-\cdot / 1 Q^{*}$ & $-\cdot / 1 \Lambda^{* * *}$ & خودشكوفايى \\
\hline-.1 .9 & $-\cdot 11$ & $-\cdot 11$ &.$- / 14$ & خود آكاهى هيجانى \\
\hline$-\cdot 1 \cdot \mathrm{V}$ & $-\cdot|r|^{* * n}$ & $-\cdot / Y^{F_{*}^{*}}$ & 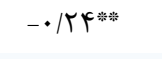 & واقعكرايى \\
\hline$-\cdot \cdot \cdot 1$ & $-\cdot 1 \cdot 1$ & $\cdot / 1$ & $-\cdot / \cdot \Delta$ & روابط بينفردى \\
\hline$-\cdot 1 \cdot .9$ & $\cdot 1 \cdot 9$ & $-\cdot / 19^{* * \%}$ & $\cdot / 1$ & خوشبينى \\
\hline$-\cdot / \mid f^{* * *}$ & $-\cdot / \cdot v \cdot$ & $\cdot \cdot \cdot \Delta$ &.$- \cdot 1.9$ & عزتنفس \\
\hline$-\cdot / 1 \Delta^{*}$ & $-\cdot / \cdot \wedge \cdot$ & $-\cdot / / Q^{*}$ & $-\cdot / 1 \varphi^{*}$ & كنترل تكانش \\
\hline$-\cdot|r| * *$ & $-\cdot 1 \cdot \Delta$ & $-\cdot 1 \cdot r$ & $-\cdot / 1 r$ & انعطاف يذيرى \\
\hline$-\cdot / 11$ & $-\cdot 1 \cdot 4$ & $\cdot / \cdot r$ & $-\cdot 1 \cdot \Delta$ & مسئوليت يذيرى \\
\hline$-\cdot / 1 Q^{*}$ & $\cdot 1 \cdot \wedge \mathrm{F}$ & $\cdot 1 \cdot V r$ & .1 .19 & همدلى \\
\hline$-\cdot 1 \cdot 1$ & 1.09 & $\cdot 1 \cdot T_{\Delta}$ & 1.09 & خودابرازى \\
\hline
\end{tabular}
جدول 1. همبستكى هوش هيجانى و تنش شغلى براساس نتايج آزمون همبستكى پيرسون 
جدول 9 نشانكر آن است كه بين هوش هيجانى كلى با شخصى فرسودىى شغلى همبستكى معكوس و معنى

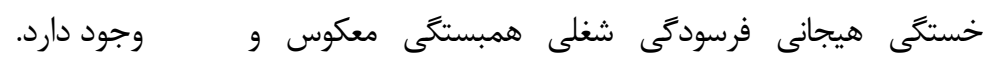
براى تعيين سهم هر يك از مؤلفهاى هوش هيجانى در ״يشبينى تنش شغلى از آزمون آمارى ضريب ركرسيون

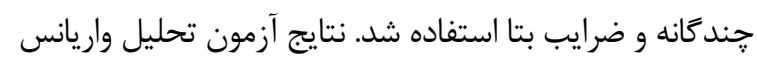

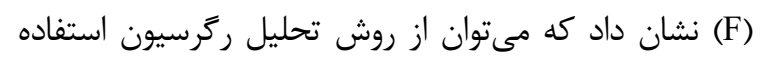

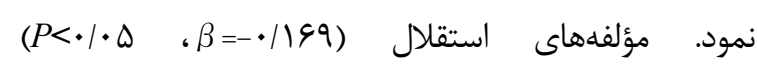

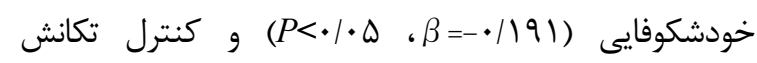

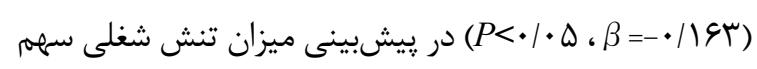

$$
\text { معنى دارى دارند (جدول • (1). }
$$

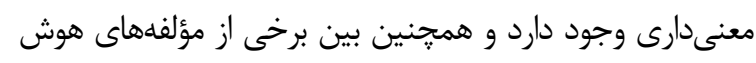

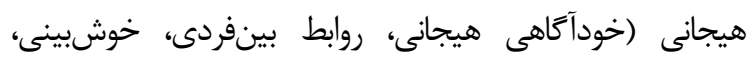

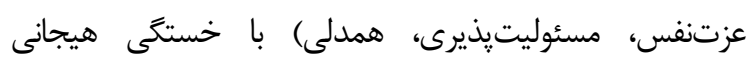
فرسودگى شغلى همبستخى معكوس و معنى دارى وجود دارد.

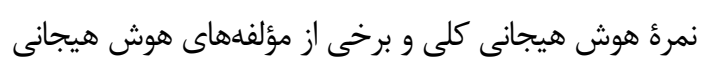

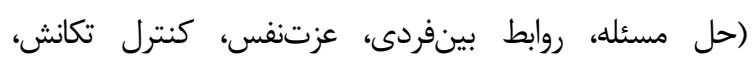

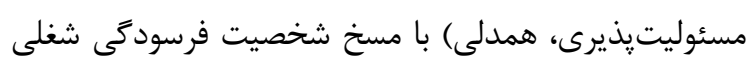

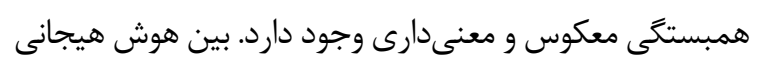

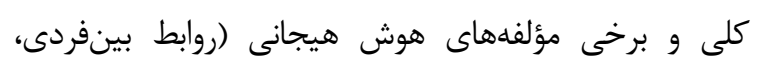

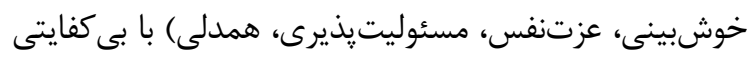

جدول 9. همبستكى هوش هيجانى و فرسودَى شغلى براساس نتايج آزمون همبستكى پييرسون

\begin{tabular}{|c|c|c|c|}
\hline كفايت شخصى & مسخ شخصيت & خستلَى هيجانى & \\
\hline$-\cdot / \Upsilon \Lambda^{\text {***** }}$ & 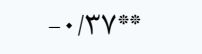 & $-\cdot / \mathcal{A} \boldsymbol{F}^{* * * *}$ & هوش هيجانى \\
\hline$-\cdot / 1 r$ & $-\cdot / \Gamma Y^{*}$ &.$/ 11$ & حل مسئله \\
\hline$-\cdot / \cdot r$ & $\cdot / \cdot r$ & $-\cdot 1 \cdot \Delta$ & خوشبختى \\
\hline$-\cdot 1 \cdot \Delta$ & $-\cdot / \cdot 4$ & -.1 .9 & استقلال \\
\hline$\cdot / \cdot r$ & $\cdot / \cdot r$ & $-\cdot \cdot \cdot r$ & تحمل فشار روانى \\
\hline $.1 \cdot 9$ & $\cdot / \cdot r$ & $\cdot / \cdot V$ & خودشكوفايى \\
\hline$-\cdot \cdot \cdot v$ & $-\cdot \cdot \cdot 1$ & $-\cdot /\left.1\right|^{4 *}$ & خود آكاهى هيجانى \\
\hline$-\cdot / \cdot f$ & -.1 .9 & $-\cdot / 1 r$ & واقعَرايى \\
\hline$-\cdot / \mu \varphi^{\text {券券 }}$ & 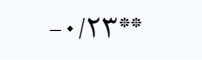 & $-\cdot / \Lambda \Lambda^{* * * *}$ & روابط بينفردى \\
\hline$-\cdot / \Gamma 9^{\text {*** }}$ & $-\cdot / 1 r$ & $-\cdot / T V^{* * * \%}$ & خوشبينى \\
\hline 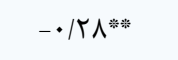 & $-\cdot / \Gamma \cdot$ 蒂券 & $-\cdot / T \Lambda^{* * * *}$ & عزتنفس \\
\hline$\cdot / \cdot r \Delta$ & $-\cdot / 1 r^{*}$ & $-\cdot \cdot \cdot 1$ & كنترل تكانش \\
\hline$-.1 \cdot 9$ & $-\cdot \cdot \cdot 1$ & $-\cdot 11$ & انعطاف يذيرى \\
\hline$-\cdot / \Gamma \Gamma^{\text {漛 }}$ & $-\cdot / \Gamma \cdot{ }^{* * *}$ & $-\cdot / T\}^{* * *}$ & مسئوليت يذيرى \\
\hline - & 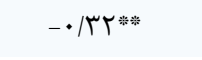 & $-\cdot / \Gamma \varphi^{* * * *}$ & همدلى \\
\hline$-\cdot / \cdot \Delta$ & $\cdot / \cdot \cdot 1$ & $-\cdot / \cdot 4$ & خودابرازى \\
\hline
\end{tabular}

جدول •1. خلاصه ضرايب ركرسيون مؤلفه هاى هوش هيجانى در يِيشبينى تنش شغلى

\begin{tabular}{|c|c|c|c|c|c|}
\hline \multicolumn{3}{|c|}{ ضرايب استانداردشده } & \multicolumn{3}{|c|}{ ضرايب استاندار رنشده } \\
\hline سطح معنى دارى & $\mathrm{T}$ & $\boldsymbol{\beta}$ & خطاى معيار & B & مدل \\
\hline$\cdot / \cdots$ & $\mid f / \cdot 94$ & & IN/qFF & $r \& V / \cdot r$. & ثابت \\
\hline (111 & $-1 / 094$ & $-\cdot / 1 \cdot 9$ & . &.$- / 9 T \Delta$ & حل مسئله \\
\hline . & $-I / \& \wedge V$ & $-\cdot 11 \cdot 9$ & $\cdot / \mathbb{F V}$ & $-\cdot / V \cdot V$ & خوشبختى \\
\hline$\cdot / \cdot r \Lambda$ & $-T / T)$ & $-\cdot 1199$ & $\cdot / \Delta \Delta \Delta$ & $-1 / \pi 99$ & استقلال \\
\hline.$/ 499$ &.$- / 8 \mathrm{VV}$ & -.1 .48 & . IFt & $-\cdot / \pi \cdot \cdot$ & حمل فشار روانى \\
\hline
\end{tabular}




\begin{tabular}{|c|c|c|c|c|c|}
\hline \multicolumn{3}{|c|}{ ضرايب استاندار دشده } & \multicolumn{3}{|c|}{ ضرايب استاندار دنشده } \\
\hline سطح معنى دارى & $\mathrm{T}$ & $\boldsymbol{\beta}$ & خطاى معيار & B & مدل \\
\hline$\cdot / \cdot \Delta$ & $-Y|\wedge F|$ & -.1191 & $\cdot / 4 \& 9$ & אחس/ו- & خودشكوفايى \\
\hline$\cdot \mid$ ETI & $-\cdot 11 \cdot 9$ & $-\cdot / \cdot \Delta \varphi$ & $\cdot / F F$. & $-\cdot / r \Delta \Delta$ & خودآكاهى هيجانى \\
\hline$\cdot 1 \cdot \Delta \varphi$ & $-1 / 9 r \Delta$ &.$- / 1 \mathrm{Fr}$ & س & $-1 / \cdot r 4$ & واقع َرايى \\
\hline$\cdot / \Delta V$. & $-\cdot 1099$ & $-.1 \cdot+4$ & $\cdot /$ Tr & $-\cdot / 4 I T$ & روابط بينفردى \\
\hline.$/ I V F$ & 1/r49 & $\cdot / 1 \cdot \Delta$ & $\cdot / 499$ & $\cdot / D F \Delta$ & خوشبينى \\
\hline$\cdot / \& V D$ & $-\cdot|V| \varphi$ & $-\cdot / \cdot \Delta \Delta$ & $\cdot|f| Q$ & $-\cdot / r q V$ & عزتنفس \\
\hline$\cdot 1 \cdot 19$ & $-T / T \Delta \Lambda$ & - & $\cdot \mid k+1$ & $-1 / \cdot 1 V$ & كنترل تكانش \\
\hline •/ १९६ & $-\cdot|\wedge \Delta|$ & $-.1 \cdot 9$. & • & $-\cdot$ / TYG & انعطاف يذيرى \\
\hline$\cdot / 1 \Delta \Delta$ & $-1 / 4 r q$ & $-\cdot / 1 \cdot \Delta$ & . $/ 4$ r. & $-\cdot|9| \Delta$ & مسئوليت يذيرى \\
\hline$\cdot|\Delta| \mid$ & $\cdot 1909$ & $\cdot 1 \cdot 49$ & •/ TqV & - MGT & همدلى \\
\hline$\cdot / V \vee \wedge$ & - /tAT &.$/ \cdot T \cdot$ & - IffF &.$/ 1 T \Delta$ & خودابرازى \\
\hline
\end{tabular}

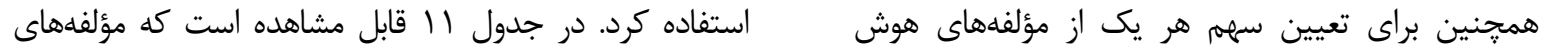

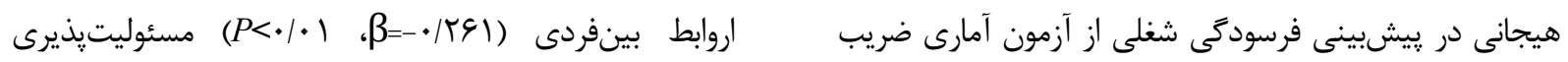

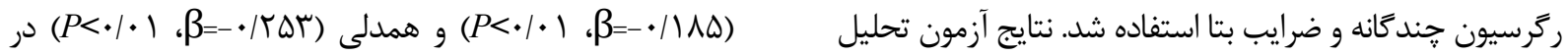

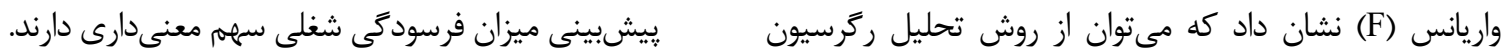

جدول Iا. خلاصه ضرايب رَّرسيون مؤلفههاى هوش هيجانى در يِشبينى فرسودَى شغلى

\begin{tabular}{|c|c|c|c|c|c|}
\hline \multicolumn{3}{|c|}{ ضرايب استانداردشده } & \multicolumn{3}{|c|}{ ضرايب استاندار دنشده } \\
\hline سطح معنى دارى & $\mathbf{T}$ & $\boldsymbol{\beta}$ & خطاى معيار & B & مدل \\
\hline$\cdot / \cdot$ & ID/9TK & & $|r / T| \&$ & $194 / 01 F$ & ثابت \\
\hline - ITFD & $-1 / 199$ & $-\cdot 1 \cdot V r$ & • /Tar & $-\cdot / r 9 \Delta$ & حل مسئله \\
\hline$\cdot / T \wedge F$ & $1 / \cdot V \Delta$ & $\cdot|\cdot V|$ & $\cdot / r \cdot V$ & • & خوشبختى \\
\hline.$|9| 9$ & $-\cdot 10 \cdot r$ & $-\cdot / \cdot r \Delta$ & $\cdot / \pi \Delta \Lambda$ & $\cdot / 1 \wedge$ & استقلال \\
\hline .1919 & $-\cdot / 1 \cdot \Delta$ & $-\cdot \cdot \cdot \cdot V$ & $\cdot / r \wedge \Delta$ & $-\cdot \cdot \cdot r \cdot$ & تحمل فشار روانى \\
\hline $.19 \mathrm{VF}$ & $\cdot \mid$ ETI & $\cdot 1 \cdot$ Tद & $\cdot \pi \cdot r$ & ./ITV & خودشكوفايى \\
\hline .1991 & $-\cdot / \cdot$ \&A & $-\cdot \cdot \cdot \cdot r$ & $\cdot / T \wedge F$ & $-\cdot / \cdot 14$ & خود آكاهى هيجانى \\
\hline$\cdot / T V V$ & $-\cdot / \wedge \wedge \Delta$ & $-\cdot / \cdot 09$ & - MTF & $-\cdot / r \cdot r$ & واقع كرايى \\
\hline$\cdot / \cdots$ & $-r / \Delta 9 \Delta$ & $-\cdot|r 9|$ & $\cdot / T F$ & $-\cdot$ - IA\&T & روابط بينفردى \\
\hline •/rTV &.$- / 914$ & -.1 .91 & $\cdot / T \Delta V$ & $-\cdot / r \Delta r$ & خوشبينى \\
\hline$\cdot / I \vee \Delta$ & $-1 / 491$ & -.1 .94 & $\cdot / T \& V$ & $-\cdot /$ TGF & عزتنفس \\
\hline$\cdot / \cdot \wedge \Lambda$ & $-1 / V I F$ & $-\cdot / 1 \cdot V$ & $\cdot / T V A$ & $-\cdot / F V V$ & كنترل تكانش \\
\hline$\cdot / T V A$ & $-1 / \cdot \wedge V$ & $-\cdot / \cdot V \cdot$ & - ITFV & $-\cdot / \pi \& \Lambda$ & انعطاف يذيرى \\
\hline$\cdot 1 \cdot \cdot 9$ & $-Y / V \wedge F$ & $-\cdot / 1 \wedge \Delta$ & $\cdot / T V V$ & $-\cdot / V V T$ & مسئوليت يذيرى \\
\hline$\cdot / \cdots$ & $-r / V \Delta \Delta$ & $-\cdot / r \Delta T$ & $\cdot / T \Delta S$ &.$- / 98 T$ & همدلى \\
\hline - KVG & $-\cdot / \Lambda \wedge \vee$ & $-\cdot / \cdot \Delta V$ & $\cdot / T \wedge V$ & $-\cdot / T \Delta F$ & خودابرازى \\
\hline
\end{tabular}


بررسى كرد. وى به اين نتيجه رسيد كه متغيرهاى سلامت

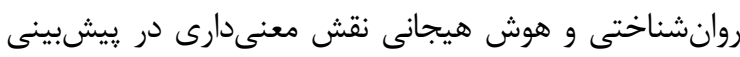

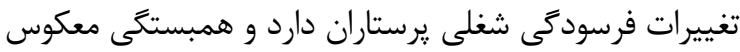
و معنى دارى بين هوش هيجانى و فرسودىى شغلى وجود دارد

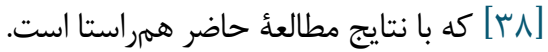

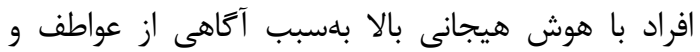

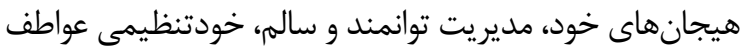

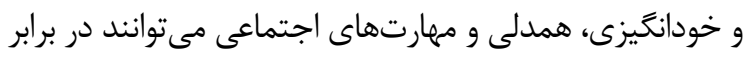

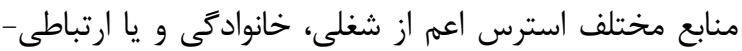

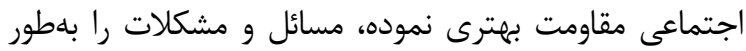

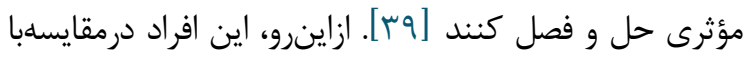
افراد با هوش هيجانى يايين بهتر مىتوانند ارتباط خوبى با فيا

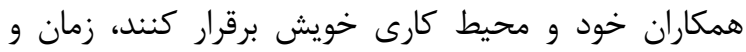
مسئوليتهاى خويش را بهتر مديريت نمايند، عملكرد

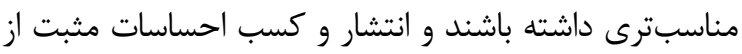
يرامون خود حضور كارآمد، شاداب و سالمترى در محيط كار و ساير زمينههاى زندگى خود داشته باشند.

\section{نتيجهل}

مههمترين يافتئ اين يزوهش حاكى از ارتباط معنادارى در

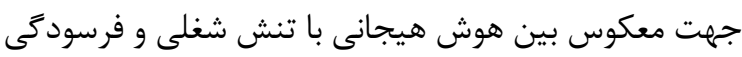
شغلى يرستاران بود. ازطرفى باتوجهبه رابطؤ معنادار بين

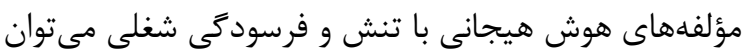

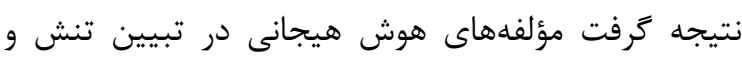
فرسودىى شغلى يرستاران سهم معنادارى داشته است.

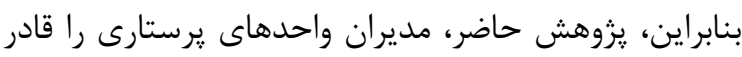

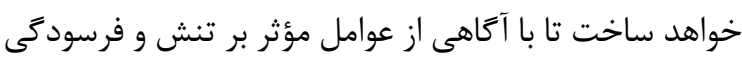

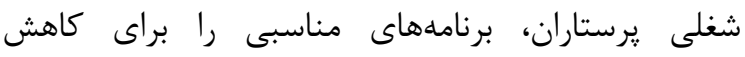
فرسودىى شغلى يرستاران تدارك ببينند. بنابراين، باتوجهبه برايه

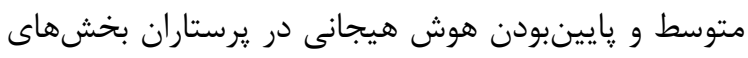

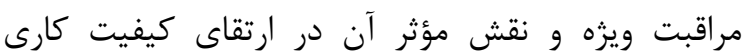
يرستاران، بيشنهاد مىشود دورههاى آموزشى و سنجش آنش

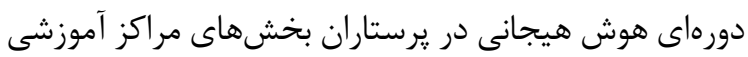

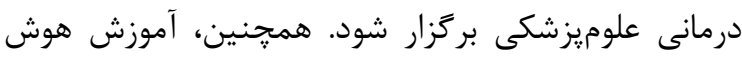

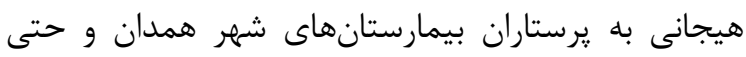

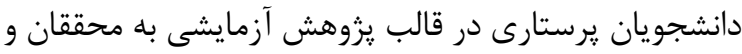

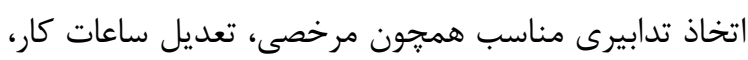

يافتهاى يزوهش نشان داد هوش هيجانى كلى با تنش شغلى كلى و مؤلفههاى وضعيت جسمانى و علاقه به شغل نئل (بهاستثناى روابط بينفردى) همبستىى معكوس و معنى دارى

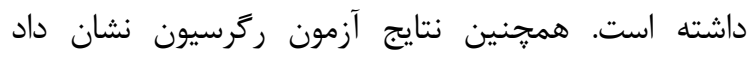

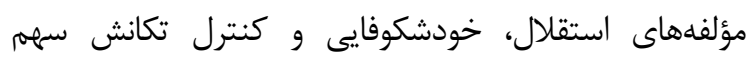
معنادارى در پِيشبينى تنش شغلى دارند . بيشترين يرستاران بخشهاى مراقبت ويره نمرة كل تنش شغلى متوسطى داشتهاند

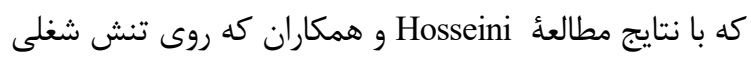

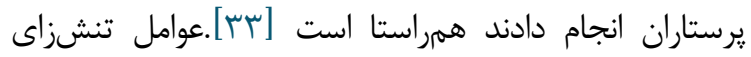

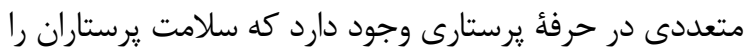

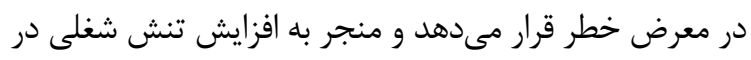

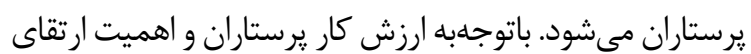

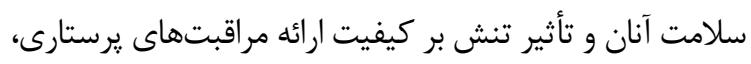

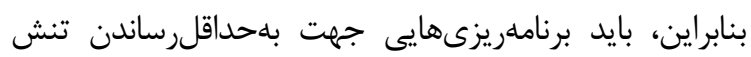
شغلى و ارتقا سلامت يرستاران توسط مسئولين طراحى و اجرا شود.

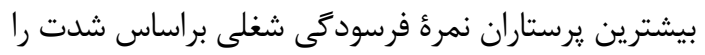

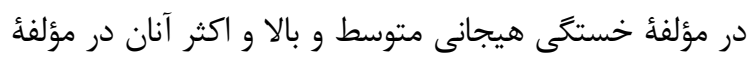

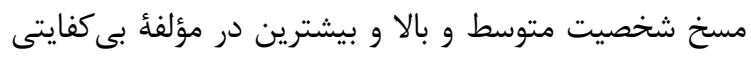

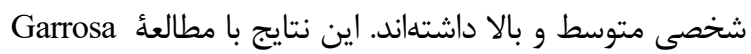

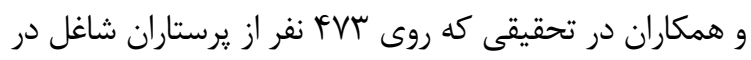

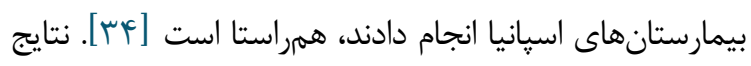

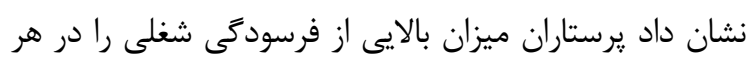

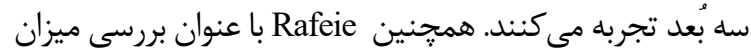

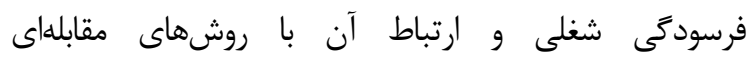
بهكار كرفتهشده توسط يرستاران شاغل در بيمارستانهاى سوانح و سوختكى تهران و مقايسٔ آن با بهياران شاغل در اين بيمارستانها به اين نتيجه دست يافت كه ميزان فرسودى إنى شغلى إنى يرستاران بالاتر از حد متوسط بوده است، همراستا است [برس]. در اين مطالعه بين هوش هيجانى كلى با مؤلفههاى فرسودىى شغلى (خستخى هيجانى، مسخ شخصيت، بى كفايتى

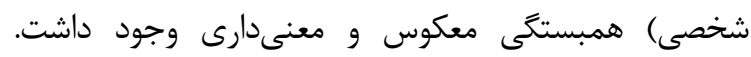

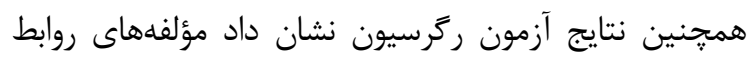

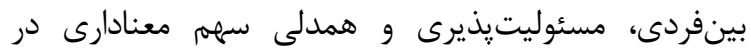

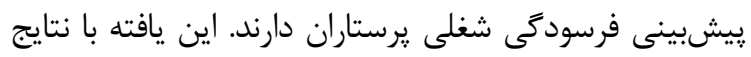

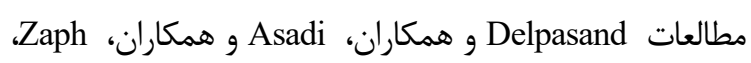

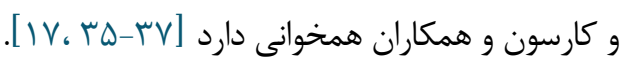
Bayrami فرسودى شغلى در يرستاران بيمارستانهاى دولتى تبريز را رانيا 


$$
\text { تعارض در منافع }
$$

$$
\text { منابع مالى }
$$

منابع مالى اين مطالعه توسط نويسندگان تامين شده است.

\section{References}

1. Golembiewski RT, Munzenrider RF. Phases of burnout: Developments in concepts and applications. New York: Praeger; 1988.

2. Tangri R. What stress costs. A special report presented by Chrysalis Performance Strategies Inc. 2003 [Last accessed on 2009 Aug 05]. Available from:http://www.StressCosts.com.

3. Beehr TA, Newman JE. Job stress, employee health, and organizational effectiveness: a facet analysis, model, and literature review. Personnel Psych. 1978; 31(4):665-99. 6570.1978.tb02118.x]

[DOI:10.1111/j.1744-

4. Baker DK. Occupational health, recognizing and preventing work -related disease and injury. 2008:41936.

5. Salimi G. Effective factors on job stress among high school principals and teachers. J Knowledge Res. 1999(5):59-80.

6. Aguayo R, Vargas C, Cañadas GR, Dela Fuente EI. Are socio-demographic factors associated to burnout syndrome in police officers? A correlational metaanalysis. Ann Psych. 2017; 33(2):383-92. [DOI:10.6018/analesps.33.2.260391]

7. Talaei A, Mokhber N, Mohammad Nejad M, Samari A. Burnout and its related factors in staffs of university hospitals in Mashhad in 2006. J Semnan Med Sci. 2008; 9(3):237-45. [Persian]

8. Maslach C. Burnout: A social psychological analysis, Hum Behav. 1976; 5:16-22.

9. Maslach C, Goldenberg J. Prevention of burnout: new perspectives. Appl Prevent Psychol 1988; 7: 63-74. [DOI:10.1016/S0962-1849(98)80022-X]

10. Khaghanizade $M$, Sirati M, Abdi F, Kaviani $H$. Determination of the amount Burnout in Nursing Staff. J Behav Sci. 2008; 2(1):51-9. [Persian].

11. Delpasand M, Nasiripoor AA, Raiisi P, Shahabi M. Relationship between emotional intelligence and occupational burnout among nurses in Critical Care Units, Iran J Crit Care Nurs. 2011; 4(2):79-86. [Persian]

12. Saeed Y, Javadi M, Sirati Nir M, Mokhtari Nouri J. Assessment and comparison of Emotional Intelligence of Nurses in General and Intensive Care Units. Iran J Crit Care Nurs. 2013; 5(4):214-21.

13. Demerouti E, Bakker AB, Nachreiner F, Schaufeli WB, A model of burnout and life satisfaction among

$$
\begin{aligned}
& \text { ياداش و تقدير، و اجراى برنامههاى آموزشى را به مسئولان } \\
& \text { امر ي بيشنهاد مى كنيم. } \\
& \text { سياسگزارى } \\
& \text { بدينوسيله، از تمامى اشخاصى كه ببا ارائه نظرات }
\end{aligned}
$$

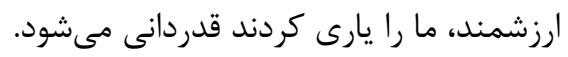

nurses, J Adv Nurs. 2000; 32(2):454-64. [DOI:10.1046/j.1365-2648.2000.01496.x] [PMID]

14. Nooryan KH, Gasparyan Kh, Sharif F, Zoladi M. The Effect of Teaching Emotional Intelligence (EI) Items on Job Related Stress in Physicians and Nurses Working in ICU Wards in Hospitals, Yerevan, Armenia. Int J Collab Res Int Med Public Health. 2011; 3(10):704-13.

15. Aghdami Baher A, Najjarpour Ostadi S, Livarjani $\mathrm{SH}$, Relationship between sense of self-efficacy and emotional intelligence with burnout in staff at the Islamic Azad University of Tabriz. J Behav Sci. 2009; 7(2):99-119. [Persian]

16. Salovey P, Hsee CK, Mayer JD. Emotional intelligence and the self-regulation of affect, In: Wegner DM, Pennebaker JW, Editors. Handbook of Mental Control, New Jersey: Prentice-Hall, 2003. 5862.

17. Delpasand MN, Raeisi P. The relationship between emotional intelligence and burnout among nurses in intensive care units. J Critic Care Nurs. 2011; 2(4):7986.

18. Porkiani MM, Mpkhtari J. The relationship between emotional intelligence and mental health nursing depression Kerman hospitals. 2012; 20(5):111-25. (Persian).

19. Shakerinia A. The relationship between emotional intelligence and self-belief came to the emergency department nurses with patient satisfaction with the treatment process. J Hospital. 2010; 9(3, 4): 15-22. (Persian)

20. Budnik, Margaret F, Emotional intelligence and burnout: Influence on the intent of staff nurses to leave nursing, School university of phoenix degree. 2003; 207.

21. Derksen L. Emotional intelligence and Adaptive Success of Nurses caring for people with Mental Retardation and Severe Behavior Problems. Ment Retard: J Pract. 2004 42(2):106-121. https://doi.org/10.1352/00476765(2004)42<106:EIAASO $>2.0 . \mathrm{CO} ; 2$ [DOI:10.1352/0047-6765(2004)422.0.CO;2]

22. Kalyoncu Z, Analysis of the relationship between emotional intelligence and stress caused by organization: A study of nurses. Busi Intell J. 2012; 5(2):334-46. [Persian].

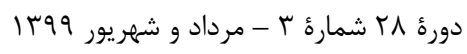


23. Ciarrochi J, Forgas JP, Mayer JD. Emotional intelligence in everyday life: a scientific inquiry. London: Psychology Press; 2001. 156-9.

24. Lopes PN, Grewal D, Kadis J, Gall M, Salovey P, Evidence that emotional intelligence is related to job performance and affect and attitudes at work. Psicothema 2006; 18:132-8.

25. Van Komen GJ, Physician Life and Career Health and Development, In: Goldman LS, Myers M, Dickstein LJ, Editors. The handbook of physician health: the essential guide to understanding the health care needs of physicians, New York: American Med Asso; 2000. 289-99.

26. Zare H, Feizi A, Mahbobi T. Study of relationship between organizational climate, occupational stress and creativity in administrative personnel (male and female) of the education office in west Azarbayjan. $\mathrm{J}$ Res Behav Sci. 2008.

27. Goleman D. Emotional intelligence. New York. Bantam Books. 1995.

28. Mohammad FI, Kianfar A, Mahmoudi S. Evaluation of relationship between job stress and unsafe acts with occupational accident rates in a vehicle manufacturing in Iran. Int J Occup Hygiene. 2010.

29. Hadaegh R. Prevalence of burnout syndrome in medical students and faculty and staff in Shiraz University of Medical Sciences. ?. 2004.

30. Maslach C, Jackson SE, Leiter MP, Schaufeli WB, Schwab RL. Maslach burnout inventory. Palo Alto, CA: Consulting psychologists press; 1986.

31. Momeni K. Burnout of Shariati hospital staff from work due to personality variables. 2001.

32. Rafeie F. Job Burnout and its relationship with coping strategies of nurses in the hospital burn. Tehran. 2001. (Persian)

33. Hosseini Z, Moeini B, Hazavehei S, Aghamollai T, Moghimbeigi A. Effect of educational stress management, based on Precede model, on job stress of nurses. J Hormozgan Uni Med Sci. 2011;15(3):200-8. (Persian).

34. Garrosa E, Moreno-Jimenez B, Liang Y, González JL. The relationship between socio-demographic variables, job stressors, burnout, and hardy personality in nurses: an exploratory study. Int J Nurs Stud. 2008; 45(3):418-27. [DOI:10.1016/j.ijnurstu.2006.09.003] [PMID]

35. Asadi J, Borgali A, Gomgari F. The relationship between job burnout and emotional intelligence and mental health among employment of Iran Khodro. Iran J Consult Res Dev. 2006; 6(22):41-56. [Article in Persian].

36. Zaph D. Emotional work and psychological well-being a review of the literature and some conceptual considerations. J Human Resource Manag Review. 2002; 12(1):237-68. [DOI:10.1016/S10534822(02)00048-7]
19 19 رابطة هوش هيجانى با تنش شغلى و فرسودگى شغلى يرستاران

37. Ganji H, Mirhashemi M, Sabet M, Bradberry-Greaves' emotional intelligence test: preliminary normingprocess. J Thought Behav. 2006;1(2):23-35. [Persian].

38. Bayrami M, Hashemi T, Ghahramanzadeh A, Alaie P. The relationship between mental health and emotional intelligence with job burnout in nurses of Tabriz state hospitals. J Res Behav Sci. 2011; 9(2(:141-7.

39. Ashlie R. Emotional competence and health. J Psych Med. 2002; 10(2):1. 